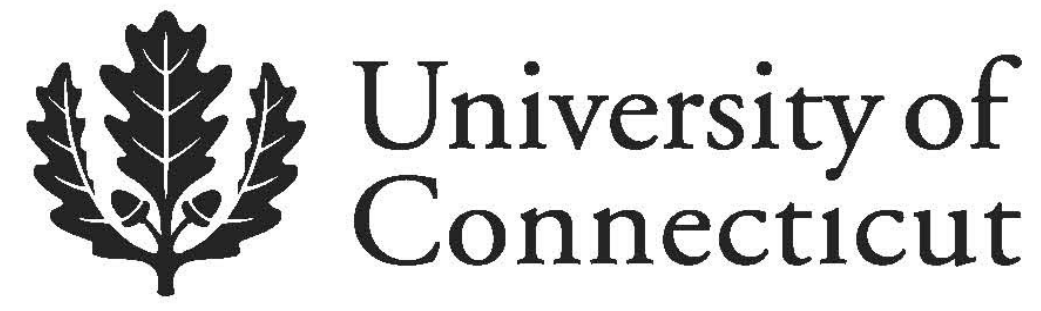

Department of Economics Working Paper Series

The Political Economy of Mass Printing: Legitimacy and Technological Change in the Ottoman Empire

Metin M. Coşgel

University of Connecticut

Thomas J. Miceli

University of Connecticut

Jared Rubin

Chapman University

Working Paper 2010-02R

January 2010, revised January 2012

341 Mansfield Road, Unit 1063

Storrs, CT 06269-1063

Phone: (860) 486-3022

Fax: (860) 486-4463

http://www.econ.uconn.edu/

This working paper is indexed on RePEc, http://repec.org/ 


\title{
The Political Economy of Mass Printing: \\ Legitimacy and Technological Change in the Ottoman Empire
}

\author{
Metin M. Coşgel*, Thomas J. Miceli**, and Jared Rubin***
}

Revised, January, 2012

\begin{abstract}
New technologies have not always been greeted with full enthusiasm. Although the Ottomans were quick to adopt advancements in military technology, they waited almost three centuries to sanction printing in Ottoman Turkish (in Arabic characters). Printing spread relatively rapidly throughout Europe following the invention of the printing press in 1450 despite resistance by interest groups and temporary restrictions in some countries. We explain differential reaction to technology through a political economy approach centered on the legitimizing relationships between rulers and their agents (e.g., military, religious, or secular authorities). The Ottomans regulated the printing press heavily to prevent the loss it would have caused to the ruler's net revenue by undermining the legitimacy provided by religious authorities. On the other hand, the legitimizing relationship between European religious and political authorities was undermined over a century prior to the invention of the press. European rulers thus had little reason to stop the spread of printing as public policy, nor could the Church have stopped it had it wanted to. The Ottomans eventually sanctioned printing in Arabic script in the eighteenth century after alternative sources of legitimacy emerged.
\end{abstract}

Journal of Economic Literature Classification: D7, H2, H3, N4, N7, O3, O5, P48, P5, Z12

Keywords: technology, printing, political economy, legitimacy, Ottoman Empire

*Professor of Economics, University of Connecticut, Storrs, CT 06269-1063, Ph: (860) 486-4662, Fax: (860) 486-4463, e-mail: metin.cosgel@uconn.edu

**Professor of Economics, University of Connecticut, Storrs, CT 06269-1063, Ph: (860) 486-5810, Fax: (860) 486-4463, e-mail: thomas.miceli@uconn.edu

***Assistant Professor of Economics, Chapman University, Orange, CA 92866, Ph. (714) 516-4530, Fax: (714) 532-6081, e-mail: jrubin@ chapman.edu 


\section{Introduction}

A fundamental puzzle of technological history is why some societies have foregone free lunches by failing to adopt technological advancements completely (Olson, 1982; Mokyr, 1990). In one of the best-known and most puzzling cases of foregone opportunity, it took the Ottomans nearly three centuries after the invention of the moveable type to sanction and offer explicit support for printing in Ottoman Turkish (in Arabic characters) in Istanbul in 1729. The delay has led to numerous speculations about Muslim reaction to new technologies, inviting various types of explanations. Some historians have attributed the delay to cultural values such as religious conservatism and obscurantist thought, others looking for the answer in socio-economic factors such as entrenched interests and institutional rigidity. ${ }^{1}$

For a satisfactory explanation of when a society adopts a new technology and why there may have been delays and restrictions, we need to identify not just the factors that may have obstructed change in some technologies but also those that have facilitated the swift adoption of technological advancements in other areas. The case of the printing press becomes even more puzzling when we consider it in relation to other technologies that were adopted quickly during the same time period. Contrary to the image of the religious and technological conservatism that seems consistent with the delayed adoption of the printing press, the Ottomans were eager to adopt the latest advancements in military technology such as the use of gunpowder and firearms (Agoston, 2005). In adopting the printing press and gunpowder weapons, often considered the most important inventions of the late Middle Ages, the Ottomans reacted quite differently, displaying a mixed image between conservatism and openness and making it difficult to explain their reaction through ad hoc factors.

\footnotetext{
${ }^{1}$ For a review of this literature, see Ghobrial (2005), Kut (1991), Roper (2007), and Sabev (2006: 47-67).
} 
We also need to develop a framework that can explain the variation in the adoption of new technologies across societies. Although the printing press faced stiff opposition and restrictions in other societies, these regulations were not as wide-ranging, long-lasting, and publicly enforced as those in the Ottoman Empire. True, the scribes guild of Paris successfully delayed the introduction of printing press, but for only 20 years. Although the Roman Catholic Church opposed some printed works, their opposition did not result in an outright ban on printing in Latin characters, but restrictions on Protestant or other "heretical" tracts. Whereas in Europe the regulations on the technology primarily catered to interest groups and short term concerns, the equilibrium that prevailed in the Ottoman Empire was regulated by the rulers, applied to all texts in Arabic characters, and lasted much longer.

Yet another piece of the puzzle is why some of the initially suppressed technologies were eventually adopted. Although the Ottomans regulated the printing press heavily for a long time, they eventually relaxed the constraints and allowed it. We thus need to consider not just the swift adoption of some technologies or the heavy regulation of others but also the differential adoption of technologies among the states and the initial suppression and eventual adoption of some technologies. For a complete explanation of technological change, we need a framework that will help identify the reasons for the differential reaction of the Ottomans to available technologies and how their reaction differed from European states and changed over time.

We examine these issues by adopting a political economy approach centered on the legitimizing relationship between the rulers, their agents, and the general public (Coşgel, Miceli, and Ahmed, 2009). We develop a simple analytical framework to capture the basic elements of the interaction between rulers and legitimizing (e.g., religious, secular, military) agents, using the framework to generate comparative statics that explain observed outcomes. Although in reality 
legitimacy can affect the ruler's objective function in many ways, we focus on its effect on the ruler's revenue. That is, a ruler who is viewed as more legitimate has access to a greater share of the surplus produced by society. However, the ruler's share of the surplus depends on technology, and since the introduction of a new technology could change these payoffs especially when they affect the ability of agents to legitimize the ruler - it could sometimes be in the best interest of the ruler to regulate the new technology to preserve the status quo. We use the model to describe the legitimizing relationship between the Ottoman rulers and religious authorities (şeyhülislam and the ulamā), military authorities (the sipāhī and janissary organizations), and secular authorities ( $\left.a^{\prime} y \bar{a} n\right)$ and discuss how new technologies changed the abilities of these agents to legitimize the ruler.

The effect of technology on legitimizing relationships explains the differential reaction of the Ottomans to advancements in printing and military technologies. They regulated printing technology heavily to ensure that it did not decrease the ruler's net revenue by undermining the legitimacy provided by religious authorities. But they readily accepted new military technologies such as gunpowder and firearms because they increased the net revenue the ruler could collect from the citizenry while having a positive effect on the military's ability to legitimize. Our approach also explains why the Europeans were quicker to accept the printing press and why the Ottomans eventually adopted it. Heavy regulations did not last as long in Europe as they did in the Ottoman Empire because different, non-religious sources of legitimacy had already emerged. Although religious legitimacy was still important to European rulers, other important sources of legitimacy were available by the advent of the press. In the same way, the Ottomans sanctioned printing in Arabic characters in the eighteenth century only after alternative sources of legitimacy emerged. 
Our approach shares insights with the literature on how interest groups influence the choice of technology. Powerful groups with vested economic interests in the prevailing technology may oppose a new technology in order to protect their rents, and their opposition may succeed if the ruler or the political process prevents the new technology from being established (Krusell and Rios-Rull, 1996; Mokyr 2002). Our approach is also related to work emphasizing the political replacement effect, where the introduction of a new technology may erode the incumbency advantage and political power of the elites. Using this approach, Acemoğlu and Robinson (2006) have shown how political leaders, fearing replacement, have blocked economic development in history and how as a result England, Germany, Russia and Austria-Hungary have displayed different patterns of industrialization.

Although our approach is similar to studies emphasizing the roles of interest groups and political elites, we differ in our stress on their ability to legitimize the ruler - which in turn augments the ruler's revenue and incentives. Rather than take the ruler's relationship with these groups as independent of technology, we examine how technological change may alter the legitimizing relation between them. Although blocking a technological development may appear to be protecting the interest of a certain group, the ruler's reaction to the new technology could more fundamentally be shaped by its influence on his legitimacy. This approach accounts for the salient interactions between institutions or other players who are likely to determine the degree to which innovation is "harmful" to the political authority. This paper therefore falls into a broader literature which analyzes the interactions between institutional authorities and agents in order to seek the conditions under which institutions and equilibrium actions endogenously change (North 1990; Greif and Laitin 2004; Greif 2006; Coşgel and Miceli 2009; Greif and Tadelis 2010; Rubin 2011a). 
Our approach also differs from a considerable body of historical and sociological literature focused on how the choice of technology was shaped by religious and cultural factors. This view has been particularly common among Eurocentric approaches and in the generalist literature. $^{2}$ The problem with these types of explanations is that they often lack a coherent whole and make ad hoc generalizations about how religious and cultural factors affect economic motivations and outcomes. ${ }^{3}$ Rather than start with questionable generalizations that would ultimately fail in the face of closer scrutiny, we focus on economic incentives and make standard economic assumptions about the motivations of the Ottomans, their agents, and the citizenry. ${ }^{4}$ We use a simple political economy model and historical analyses to explain their reactions to new technologies.

In what follows, we first formalize our argument in a simple political economy model of legitimacy and technological change. We then discuss the religious, secular, and military agents in the Ottoman Empire and the legitimizing relationship between these agents and political rulers. Applying our model to the Ottoman Empire, we use it to explain the differential reaction to technological change; namely why the Ottomans initially heavily regulated the printing press while it was swiftly adopted in Europe, why the Ottomans readily accepted advancements in military technology, and why they eventually accepted the printing press.

\section{The Model: Legitimacy, Political Economy, and New Technology}

\footnotetext{
${ }^{2}$ See, for example, Cipolla (1966), Jones (1987: Chapter 9), Goldschmidt (2002: Chapter 9), and Lewis (1982: Chapter 9). For a classic criticism of this approach, see Said (1978).

${ }^{3}$ A similar problem arises in the field of "Islamic economics", where outcomes are based on the assumption of an economy based on Islamic principles that is consistent with economic incentives. This field is thoroughly deconstructed by Kuran (2004).

${ }^{4}$ This is consistent with the recent economic approaches to the history of Muslim and Middle Eastern societies and empirical analysis of the relationship between Islam and democracy. See, for example, Greif $(2002,2006)$, Iannaccone and Berman (2006), Platteau (2008), Coşgel, Miceli, and Ahmed (2009), Kuran (2010), Rubin (2011a), Potrafke (2011) and Chaudhary and Rubin (2011).
} 
To express the basic argument in a formal framework, we develop a political economy approach to technological change that is centered on the notion of legitimacy. Consider the interaction between the ruler and an agent whose role it is to support, or legitimize, the ruler. The agent could represent a religious authority, a military authority, or an aristocratic class (nobility). The citizenry produces a gross surplus, $S_{0}$, that is limited by resources and technology. The objective of the ruler is to extract as much of that surplus as possible for his private consumption.

Legitimacy can come from various sources (Beetham, 1991; Gilley, 2009; Hardin, 2007; Levi, 1988). Indeed, religious legitimization has historically been extremely important for rulers in both Islam and Christianity, as it permits them to extract more from the populace, discourages revolt, and enables access to property rights assignment (Mann 1986; Greif 2002, 2006, 2010; Greif and Tadelis 2010). ${ }^{5}$ In an approach similar to Wintrobe's (1998) analysis of the sources of power in dictatorships, we divide sources of legitimacy into two factors, force and loyalty, where each can be produced by capital and labor inputs. Force, for example, can be produced by weapons and soldiers, ${ }^{6}$ while loyalty can be produced by books and educators. ${ }^{7}$

Although legitimacy serves many functions in reality, we focus on its role in increasing the ruler's revenue. Consider a ruler who imposes a nominal tax rate of $t$ on the citizenry, so that under conditions of perfect compliance, total tax revenues would be $t S_{0}{ }^{8}$ In reality, however, enforcement costs and corruption will dissipate a fraction $\delta$ of each tax dollar, yielding the ruler net taxes of $(1-\delta) t S_{0}=\beta_{0} S_{0}$, where $\beta_{0} \equiv(1-\delta) t$ is the effective tax rate. The role of legitimizing

\footnotetext{
${ }^{5}$ For more on the role that religious authorities have played in legitimizing the state in the Islamic and Christian worlds, see Mann (1986), Greif (2002, 2006, 2010), Platteau (2008), Coşgel and Miceli (2009), Coşgel, Miceli, and Ahmed (2009), Greif and Tadelis (2010), Rubin (2011a), and Chaudhary and Rubin (2011).

${ }^{6}$ For a recent analysis of coercive legitimacy, see Hurrell (2005).

${ }^{7}$ We do not endogenize the source of legitimacy. We merely assume that when rulers "purchase" more support from religious authorities they are viewed as more legitimate, and thus have access to a greater share of the economy's surplus. Underlying this assumption is a historical relation between the citizenry and the legitimizing agents that is clearly exogenous to the present choice of technology adoption, which is at the center of our model.

${ }^{8}$ We treat $t$ as fixed, but in a fuller model, it presumably would be the rate that drives citizens to their reservation utility (see, for example, Cosgel and Miceli (2009)).
} 
agents in this setting is to support the ruler so that citizens are more compliant in paying taxes. In particular, greater legitimacy will tend to reduce $\delta$, resulting in a higher value of $\beta_{0}$, and hence more revenue.

Suppose that in this setting a new technology emerges, denoted by $\boldsymbol{\Theta}$, that potentially increases the available surplus. Suppose in particular that if the citizenry were given complete freedom to adopt the new technology, the gross surplus would be $S\left(\theta^{*}\right)>S_{0}$, where $\theta^{*} \in \boldsymbol{\Theta}$ represents the most productive (surplus-maximizing) use. Thus, all else equal, the ruler would readily allow the technology because it would increase his net tax revenue to $\beta_{0} S\left(\theta^{*}\right)$, holding $\beta_{0}$ fixed.

At the same time, however, the new technology may be used in society in ways that either further legitimize the ruler, or possibly that undermine his legitimacy. For example, a new military technology could be used to intimidate citizens into paying taxes, or to threaten an armed uprising against the ruler. Likewise, the printing press could be used to publish books that either praise or undermine the ruler's legitimacy. For these reasons, the ruler might find it advantageous to limit or suppress the technology, for example by allowing only certain uses.

To be concrete, let the gross surplus, written as a function of the new technology, be $S(\theta)=S_{0} \theta$, where we order the possible uses so that $\theta=1$ is the value of the current technology and higher values of $\theta$ represent more productive uses (thus, $\theta^{*}>1$ ). Also let the effective tax rate be given by $\beta(\theta)=\beta_{0} e^{\gamma \theta}$, where $\gamma>0$ for those uses that enhance the ruler's legitimacy (implying that $\beta(\theta)>\beta_{0}$ ), and $\gamma<0$ for uses that undermine it (implying that $\left.\beta(\theta)<\beta_{0}\right) .{ }^{9}$ The ruler's net tax revenue as a function of the new technology is therefore given by

$$
\beta(\theta) S(\theta)=\beta_{0} S_{0} \theta e^{\gamma \theta}
$$

\footnotetext{
${ }^{9}$ We thank a referee for suggesting this functional form.
} 
which may be increasing or decreasing in $\theta$. Although the technology increases the gross surplus unambiguously (by assumption), the ruler may nevertheless choose to suppress or regulate it if he fears that it could be used to reduce his share of that surplus. In this context, regulation would consist of placing an upper bound, $\theta_{r}$, on the allowable uses, where $1 \leq \theta_{r} \leq \theta^{*}$.

To determine the ruler's optimal strategy, differentiate (1) with respect to $\theta$ to obtain

$$
\beta_{0} S_{0} e^{\gamma \theta}(1+\gamma \theta)
$$

which may be positive, negative, or zero depending on the sign and magnitude of $\gamma$. Figure 1 shows the possible cases. The horizontal axis in the various diagrams shows different possible uses of the technology, with $\theta=1$ representing no use (suppression), and $\theta=\theta^{*}$ representing the socially optimal use (i.e., the use that maximizes $S(\theta)$ ). As noted, different uses are ordered along the axis so that $S(\theta)$ is monotonically increasing in $\theta$. The left-hand diagram in each panel shows the effect of $\theta$ on the ruler's legitimacy, as measured by the effective tax rate, $\beta(\theta)$, while the right-hand diagram shows its effect on the ruler's net tax revenue.

\section{[Figure 1 here]}

Panel (a) shows the case where the ruler allows the technology to be adopted without regulation. This case will be relevant when the ruler's net tax revenue is increasing in $\theta$ for all feasible values of $\theta$. Given (2), this will be true when $\gamma>-1 / \theta^{*}$. (Note that $\beta(\theta)$ is shown as strictly increasing in the left-hand graph, which will be the case when $\gamma>0$. When $0>\gamma>-1 / \theta^{*}$, $\beta(\theta)$ is decreasing in $\theta$, but net tax revenues will still be increasing for all $\theta \in\left[1, \theta^{*}\right]$.) Clearly, since there is no conflict of interest between the ruler's private interests and that of society in this case, he will allow the technology to be freely adopted. That is, $\theta=\theta^{*}$ and the outcome is socially optimal. 
In contrast, panels (b) and (c) in Figure 1 show situations in which the ruler's legitimacy is undermined by the new technology; that is, $\gamma<-1 / \theta^{*}$, so that $\beta$ is decreasing in $\theta$. When this is true, the ruler may benefit from either restricting or outright banning the new technology. Merely restricting the technology allows some uses but not others, thus allowing society (and the ruler) to benefit from some of the potential gains in productivity, while at the same time preventing those uses that might undermine the ruler's legitimacy. Panel (b) shows this case, where the maximum allowable use of the technology $\theta_{r}$, is assumed to be an interior solution. Thus, setting (2) equal to zero and solving yields $\theta_{r}=-1 / \gamma$, where $1<\theta_{r}<\theta^{*}$ by constuction. ${ }^{10}$ In this case, some uses of the technology are allowed $\left(1 \leq \theta \leq \theta_{r}\right)$, but others are foregone $\left(\theta_{r}<\theta \leq \theta^{*}\right)$.

The final case, where the ruler suppresses the technology altogether, is shown in panel (c) of Figure 1. Here, the technology is so threatening to the ruler's legitimacy that he is better off preventing its adoption altogether, despite the loss in terms of foregone productivity. In this case, which holds when $\gamma<-1$, (2) is negative for all feasible values of $\theta$, so the ruler's optimum occurs at $\theta=1$. As a result, society reaps no gains from the available technology.

One factor not considered in the foregoing model is that restricting or suppressing the new technology (cases (b) and (c)) will generally involve monitoring costs, and/or the payment of bribes to agents aimed at ensuring that they will refrain from the forbidden uses. Let $C(\theta)$ be this cost, which we write generally as a function of the allowed use, $\theta$. (We do not make any a priori assumption about whether $C$ is increasing or decreasing in $\theta$ since both cases are possible, depending on the nature of the technology.) Taking these costs into account, the ruler now chooses $\theta$ to maximize

$$
\beta(\theta) S(\theta)-C(\theta)
$$

\footnotetext{
${ }^{10}$ This requires that $-1<\gamma<-1 / \theta^{*}$, where, recall, $\theta^{*}>1$. Note that the second-order condition for a maximum is satisfied in this case given $\gamma<0$.
} 
The effect of adding these costs will be to reduce the likelihood of restrictions on technology, except in those cases where the new technology actually lowers the costs of regulation or suppression (as may be the true, for example, of certain military innovations). The qualitative conclusions of the above model, however, are unaffected by this extension.

\section{Agents and Legitimacy in the Ottoman Empire}

To apply this framework to technology adoption in the Ottoman Empire, we elaborate on how the Sultan acquired legitimacy from religious, secular, and military authorities and how technology affected the net revenue he extracted from the population. At the time of the invention of the printing press in the fifteenth century, the Ottoman Sultan ruled over a predominantly agrarian society engaged in agricultural production. There were also numerous towns of varying sizes, with inhabitants engaged in trade, manufacturing, and more specialized activities such as fishing and mining. The Ottomans used a variety of taxes to raise revenue from the surplus generated by these activities. Information from the archival records of this period shows that they developed a sophisticated system of taxation that consisted of three general categories of taxes, namely personal taxes that were based on a taxpayer's marital and economic status, trade taxes based on the goods brought to the market, and production taxes based on either the quantities of inputs, outputs of productive activities, or the enterprise as a whole (Coşgel, 2005). The revenue from these taxes in principle belonged to the Sultan's treasury. Adopting a multi-tiered system of administration, the Ottomans allocated part of the revenue to provincial governments and local services to support their operations (Coşgel and Miceli, 2005).

The Ottomans relied on various agents to raise the proportion of the surplus they could extract as taxes. To analyze how these agents provided legitimacy to the Sultan, we employ Hourani's (1981) discussion of urban notables, whose political influence rested on their access to 
authority while possessing social power independent of the ruler. Hourani (1981: 44-45) identifies three such groups in the Arab provinces, namely the religious, military, and secular authorities. More specifically, the first group consisted of the $u l a m \bar{a}$, "whose power was derived from their religious position." In the second group were the leaders of the local garrisons, who "had immediate control of armed force, but ... had a certain independence of action." The third group included the " 'secular notables' (a'yan, ăgas, amirs) ... individuals or families whose power might be rooted in some political or military tradition, the memory of some ancestor or predecessor; or in the 'asabiyya of a family or of some other group which could serve as its equivalent; or in the control of agricultural production through possession of malikanes or supervision of waqfs." With appropriate modifications, these categories help to identify not only the groups that influenced politics in the Arab provinces but also the sources of legitimacy for the Sultan in the Empire as a whole.

There was a centralized religious establishment in the Ottoman Empire consisting of individuals trained in the Islamic Law who served primarily as teachers (mudarris) educating the Muslim community, judges ( $q \bar{a} d \bar{l})$ resolving legal disputes, or jurisconsults (muftī) offering legal opinions. Although the basic functions of religious authorities followed from practices established by previous Islamic societies, the Ottomans added a distinct dimension by incorporating the religious hierarchy into the governmental structure and supported them financially. They established the office of the chief jurisconsult (şeyhülislām), a powerful position that was appointed by the ruler. Unlike rulers in previous Islamic societies who did not engage in an agency relationship with the religious authority, the Ottomans were able to manage the entire hierarchy through their prerogative to appoint the chief jurisconsult (Coşgel, Miceli, and Ahmed, 2009). 
Religious authorities conferred legitimacy through loyalty, which encouraged citizens to believe that the Ottoman sultan had the right to rule and the power to provide protection and other public goods and services - and that he should therefore have the right to collect taxes. Given the power of religious belief, the word of the religious authorities could provide a single, coherent, and effective source of legitimacy (Greif 2002, 2010). Moreover, given their power to interpret the Islamic law, they could affect the Sultan's revenue directly by issuing legal opinions regarding the rates of taxation accordingly. This was perhaps most evident in the case of Ebu'ssu'ud, the famous chief jurisconsult of Süleyman the Lawgiver in the sixteenth century, who harmonized secular administration with religious law by allowing rulers wide discretion in setting the tax rates. This was clearly sanctioned by some of Ebu's-su'ud famous interpretations. When asked for an interpretation on the question of whether the tithes were to be collected literally at the canonical rate, he argued that it was "not necessary that it be levied [at a rate of] one tenth. It is imposed according to what the land can support and is licit up to a half" (Imber, 1997, p. 127).

The power of religious authorities depended on their role in the transmission of knowledge, an essentially oral process in early Ottoman society prior to the introduction of the printing press. For centuries, religious scholars had been trained through a person-to-person relationship between students and teachers. Robinson (1996: 223) has argued that the reason for heavy emphasis on oral transmission was that "Muslims were fundamentally skeptical of the written word, and particularly the written word studied without supervision, as a reliable means of communication." This was particularly true for non-native speakers of Arabic, who constituted the majority of Ottoman subjects and had to rely on others' interpretation of the Qur'an and other great Arabic texts. Commenting on methods of instruction that applied to such 
cases, Ibn Khaldûn (1967: 431), the great Muslim scholar and historian of the fourteenth century, commented that "when the student has to rely upon the study of books and written material and must understand scientific problems from the forms of written letters in books, he is confronted with another veil, (namely, the veil) that separates handwriting and the form of letters found in writing from the spoken words found in the imagination." To acquire authority over the transmission of a text from his teacher under the traditional system of ijaza, a student had to read it out loud and demonstrate his ability to understand its meaning to the satisfaction of the teacher.

The power of religious authorities in the transmission of knowledge gave them a monopoly advantage in the provision of legitimacy through loyalty. The production of loyalty was a labor intensive process through which religious authorities supported the ruler or the state through sermons and speeches delivered as part of their official function. The Friday sermon was traditionally delivered in the ruler's name as a symbolic manifestation of recognizing his sovereignty. Religious authorities also assisted the rulers in controlling the limited number of books available for public use in libraries, scrutinizing their contents and ensuring the suppression of items that could threaten loyalty (Göçek, 1987: 109). To ensure the stability of loyalty-based legitimacy, Ottoman rulers compensated religious authorities and sought to assimilate their institutions into the state bureaucracy.

Secular authorities conferred legitimacy in a parallel fashion, through secular sources of loyalty. They commanded loyalties as eminent individuals who led tribes, owned land or other resources, belonged to a prominent family, or possessed other sources of social, economic, or political power (Hourani, 1981; Özkaya, 1994). These individuals featured frequently in the official communication between the central government and local officials. Decrees referred to them as $a^{\prime} y \bar{a} n$ or eşraf (e.g., $a^{\prime} y \bar{a} n-l$ vilāyet) in ways that acknowledged their local significance 
along with government officials, and their role as agents that conferred legitimacy. They were variously involved in the state's relationship with the local population, performing such tasks as the collection of taxes, representation of local interests, maintenance of public order, and management of civil disputes.

In contrast to religious authorities, military authorities conferred legitimacy through force. Whereas the religious or secular authorities had a comparative advantage in generating loyalty from religious or secular commitments, military authorities had a comparative advantage in generating force by using manpower and weapons. The commanders of the Janissaries, cavalrymen (sip $\bar{a} h \bar{\imath})$, and other armed forces were in principle at the Sultan's disposal, ready to employ their troops to secure his legitimacy.

The comparative advantages of religious, secular, and military authorities to confer legitimacy varied significantly among regions of the Ottoman Empire because of differences in the composition of population. Religious authorities were less effective in providing legitimacy in the Balkans, a region dominated by Christians, than in Istanbul, Anatolia and the Arab lands, where it was easier to establish legitimacy through religious loyalty among the predominantly Muslim population. Military authorities were more effective in the Balkans, owing to their ability to provide legitimacy through force. Although we do not have reliable statistics on the regional or religious distribution of population in the fifteenth century to determine the relative importance of different sources of legitimacy at the introduction of the printing press, Barkan's (1953: 11) estimates of the numbers of Muslim and non-Muslim households during the period between 1520 and 1530 can be used as a close approximation. According to these figures, about 60 percent of households (outside of Istanbul--the capital city) were Muslims during this period, the proportion ranging from about 20 percent in the Balkans to 99 percent in Anatolia. 
The abilities of religious, secular, and military authorities to confer legitimacy changed significantly over time. Although the military authorities generally continued to enjoy a consistently high ability to confer legitimacy throughout the empire's long history (though by different units), the ability of religious and secular authorities shifted significantly during the period leading to the eighteenth century. Specifically, as we will detail below, while the religious authorities suffered a significant setback in their ability to generate loyalty, secular authorities experienced a rise in their importance, resulting in a period known as the age of the a'yāns (İnalcık, 1977; Özkaya, 1994). By reducing the negative effect of mass printing on the Sultan's legitimacy, these changes altered the Ottomans' attitude toward the printing press in the eighteenth century.

\section{Why the Ottomans Heavily Regulated the Printing Press}

It is commonly stated in Ottoman historiography that upon learning about the invention of the printing press Sultan Bayezid II opposed the new technology vehemently. According to this version of events, he issued an edict in 1485 (within decades after the appearance of Gütenberg's first book published by the moveable type in Germany), banning printing in Ottoman Turkish (in Arabic characters). Renewed in 1515 by his son, Sultan Selim I, the decree stated that "occupying oneself with the science of printing was punishable by death". ${ }^{11}$

The authenticity of the decree that officially banned the printing press with such a strong threat of punishment, thus supposedly showing the severity of the Ottoman reaction to the new technology, has not been well-established. Although Mystakidis (1911: 324) mentioned the presence of such an edict in the first volume of Türk Tarih Encümeni Dergisi, the validity of this claim was quickly challenged by Efdaleddin (Tekiner) Bey (1916) in the same publication five

\footnotetext{
${ }^{11}$ English translation from Göçek (1987: 112).
} 
years later on the grounds that Ottoman archives do not house edicts issued prior to 1553 and thus Mystakidis could not possibly have seen it. Despite this correction and the fact that no such edicts have since been uncovered, the secondary literature has for the most part accepted the presence of the edict as a matter of established fact. ${ }^{12}$ Although studies of the history of Turkish printing, such as those by Gerçek (1939: 17-18) and more recently Ghobrial (2005), have continued to challenge the received view, the presence of the edict has continued to occupy a central place in the literature on the Ottoman Empire.

Regardless of questions about the authenticity of the frequently quoted edict banning the printing press, other evidence suggests that some type of severe restriction on printing in Ottoman Turkish was in place. Prior to setting up the first officially sanctioned press that could print in Ottoman Turkish in the Empire, İbrahim Müteferrika petitioned Sultan Ahmed III with his partner Sait Efendi with a short treatise that described the benefits of printing and thereby obtained an explicit permission to start printing. ${ }^{13}$ The language of the edict that allowed him to print makes it clear that a major restriction was being lifted, as it states that the new technology would be "unveiled like a bride and will not again be hidden." (Atiyeh, 1995: 285) The evidence on the books found in the Empire from this period also supports the presence of severe restrictions. The only non-manuscript books in Arabic script published before the eighteenth century were imported from abroad.

The Ottomans did not delay adopting the printing press because they were unaware of its invention or lacked technical expertise. ${ }^{14}$ Soon after the introduction of the printing press,

\footnotetext{
${ }^{12}$ See, for example, Finkel (2005: 366) and Savage-Smith (2003: 656).

${ }^{13}$ For the personal history of Müteferrika and the early history of printing in the Ottoman Empire, see Babinger et al. (2004), Berkes (1962), Sabev (2006), and Topdemir (2002).

${ }^{14}$ For history of the printing press in the Ottoman Empire and various explanations of the delay in adopting it, see Adıvar (1943: Ch. 6), Gerçek (1939), Kut (1991), Robinson (1993), Sabev (2006), Savage-Smith (2003), and Szyliowicz (1986).
} 
various groups were able to demonstrate their ability to operate the press and acquired

permission to do so. Religious minorities were allowed to set up their own presses as early as the fifteenth century with the provision that they could only print in non-Arabic characters. Jewish immigrants from Spain and Portugal were allowed to establish a press in Istanbul in 1493, soon publishing the Torah and other religious and secular texts in Hebrew characters. Armenians were similarly able to establish a press in the 1560s, printing books in the Armenian alphabet with fonts brought from abroad (Gerçek, 1939: 26-29). Although the Ottoman subjects thus possessed the necessary skills to adopt the printing press, there was a ban on printing in the Arabic script.

While the peculiarities of the Arabic script presented unique challenges, they were not insurmountable. Several parties managed to print in Arabic characters outside of the Empire as early as the beginning of the sixteenth century. The Qur'an, for example, was printed in Venice in 1640 (Gerçek, 1939: 20). In 1588, two Italian merchants received permission from the Ottoman sultan to import books. ${ }^{15}$ Among those imported from abroad were Christian religious texts printed in Arabic. Several presses were established in Italy and Paris that were capable of printing in Arabic characters long before the Ottomans finally sanctioned the technology in the eighteenth century. ${ }^{16}$

The heavy regulation of the printing press is puzzling because the Ottoman sultans could have raised the society's taxable surplus and thus their own revenue by allowing it to operate freely. The new technology would have raised the surplus directly through its effect on the market for books and indirectly through positive externalities that would have benefited other sectors. The direct effects on the market were particularly obvious for the publication of the Qur'an and other religious texts, for which the demand was presumably high, regardless of the

\footnotetext{
${ }^{15}$ For an English translation of the decree, see Atiyeh (1995: 283).

${ }^{16}$ Printing in Arabic characters inside the Empire started in Aleppo in 1706 with the publication of Arabic New Testament and other Christian works (Roper, 2010: 38).
} 
literacy rate. This was certainly the case in Europe, where there was a huge demand for bibles after the spread of the press despite low literacy rates. Mass production of religious and secular texts could have raised the output and revenues of the book industry significantly.

The indirect effects of mass printing on the aggregate surplus would also have been positive through economic development. As Buringh and van Zanden (2009: 409) have argued, books were "strategic commodities [that were] a crucial part of the information infrastructure and, in a way, the 'hardware' which stored all ideas." Likewise, noting the high correlation between reading ability and human capital formation, Baten and van Zanden (2008) have recently used per capita book production as a proxy variable for advanced literacy skills and found a significant relationship between book production and the onset of modern economic growth in Europe ${ }^{17}$ By promoting mass printing technologies, the Sultan would have enhanced the production and accumulation of economic ideas that were essential for economic development and surplus generation.

Although the expected magnitude of the rise in surplus may have been lower in the Ottoman Empire than in Europe, the important thing is that it was still positive. True, wages and literacy rates were significantly lower in the Ottoman Empire than in Western Europe, indicating a lower demand for books and a less significant effect on economic growth than in Europe. Özmucur and Pamuk (2002) estimated real wages of skilled and unskilled workers in Istanbul and other Ottoman cities to have been significantly lower than those in northwestern Europe as early as the beginning of the sixteenth century, indicating a lower willingness to pay for books and a less extensive and profitable book industry. Low incomes and low demand for books also

\footnotetext{
${ }^{17}$ Dittmar (2011) finds a similar relationship between the printing press and subsequent European economic growth. Chilosi and Volckart (2010) show that the press also contributed to greater market integration prior to the Reformation, as news-sheets with financial information greatly increased information flows. Eisenstein (1979) has also argued that the printing press was "an agent of change" in European history, setting off significant events such as the rise of modern science and the spread and permanence of Renaissance in Europe.
} 
reduced the likelihood of forming a cycle of intensified reading activity that would have led to higher levels of human capital and incomes. Literacy rates were also most likely lower in the Ottoman Empire than in Western Europe during this period, though there are no systematic studies that can confirm this reliably. ${ }^{18}$ Despite relatively low demand for books and rates of literacy, the expected effect of mass printing on the society's surplus (and thus the gross revenue available to the Ottoman rulers) was still positive. Introducing the press would have ultimately increased productivity through its effect on human capital, as increased access to readable material would have encouraged investment in literacy. Although the direct and indirect effects of mass printing would have taken longer to materialize in the Ottoman Empire than in Europe, the society's surplus was much larger with the press than without. In short, stated more formally in terms of the model, $S\left(\theta^{*}\right)>S_{0}$. The puzzle that needs an explanation is why the Ottomans decided to forego this opportunity and suppress the technology.

We argue that the Ottoman rulers banned printing in Arabic characters because they were fearful of its effect on their legitimacy. By undermining the ability of religious authorities to confer legitimacy, the printing press would have raised the cost of collecting taxes and lowered the ruler's revenue. This would happen through two related processes, namely the switch from oral to written (mass) transmission of knowledge and the loss in the ability of religious authorities to confer legitimacy. As discussed earlier, the transmission of knowledge was an essentially oral process in the early Ottoman society, based on a labor-intensive technology that involved direct, person-to-person relationship between students and teachers. The introduction of

\footnotetext{
${ }^{18}$ Historians generally consider literacy rates to have been very low in the Ottoman Empire, around 2-3 percent, even as late as the beginning of the nineteenth century, compared to much higher rates ranging between 10 and 30 percent in Western Europe in the sixteenth century (Quataert, 2000: 167; Baten and van Zanden, 2008: 221).This is consistent with the strength of oral tradition in the transmission of knowledge in the Islamic world (Nasr, 1995; Robinson, 1993). Yet, these differences may be a result of the relatively early introduction of printing in Europe - as more books (beyond bibles) were produced, feedback between the demand and supply of books increased the quantity of readable material as well as the literate population.
} 
the printing press was a significant threat to the stability of this process. Once adopted, mass printing would have altered the technology of transmitting knowledge, making it more capitalintensive and providing knowledge directly from books or from literate individuals not necessarily affiliated with religious authorities.

By altering the transmission of knowledge, mass printing would have diminished the comparative advantage of religious authorities in providing legitimacy through loyalty. The religious authorities would have lost their monopoly in the transmission of knowledge and their power in convincing the public on the legitimacy of the ruler. This could ultimately lead to a situation in which the net revenue of the ruler could fall with the full adoption of the new technology; that is $\beta\left(\theta^{*}\right) S\left(\theta^{*}\right)<\beta_{0} S_{0}$.

As developments around the world later showed, such fears were well-founded because mass printing gradually led to a decline in the comparative advantage of religious authorities in both Europe and the Islamic world (Eisenstein, 1979; Robinson, 1993: 245-46). The rulers ultimately stood to lose from this development because they faced the risk of declining control over the provision of legitimacy through loyalty. While the ulema made up a good portion of the literate population and certainly could have employed the press for propaganda or communication, the potential downsides were devastating. As noted below, the leaders of the Protestant Reformation were able to use the press to undermine the Church despite low levels of literacy in Europe (Rubin 2011b). The mechanisms they employed - pictures and public readings - could easily have undermined religious authority. Indeed, the Ottoman sultans were well aware of what was happening in Europe, and the fear of similar events played a role in their imposing regulations on the press (Pedersen 1984; Huff 1993). 
In the end, it was in the Ottomans' best interest to regulate the technology to avoid the threat to their legitimacy. ${ }^{19}$ Another factor affecting this decision was the cost of monitoring the regulations, $C(\theta)$. The cost was lower for bans on specific types of fonts rather than certain titles, which is how the Ottomans initially regulated the press in the early decades of the technology. As noted, they banned printing in Arabic characters but allowed religious minorities to set up their own presses. Jewish immigrants were able to publish the Torah and other books in Hebrew characters and Armenians were similarly able to print the Bible and other books in the Armenian alphabet, whereas Muslims were not allowed to publish the Qur'an or any other religious or secular text in Arabic characters. As we will detail below, the Ottomans started to relax these restriction in the eighteenth century after alternative sources of legitimacy emerged.

\section{Why European States Quickly Adopted the Printing Press}

Unlike in the Ottoman Empire, the printing press spread quite rapidly throughout Western Europe after Gütenberg introduced his invention in Mainz in 1450. Although some organized groups (such as the Stationers' Company in England and the scribes' guild of Paris) resisted the new technology and were successful in delaying its adoption for some time, most rulers accepted it without much delay. By 1480, there were over 110 presses operating throughout a crosssection of important Western European towns, arising (amongst other places) in Germany, Italy, France, Netherlands, Belgium, Spain, and England (Febvre and Martin, 1976: ch. 6).

\footnotetext{
${ }^{19} \mathrm{It}$ is also possible that the religious authorities were worried with maintaining cohesion in their ranks after the advent of the press, not the loss of their monopoly on the transmission of the Qur'an. While we cannot discount this possibility, the decentralized nature of Islamic religious institutions make this argument difficult to accept as the sole motivating factor of religious authorities attitudes towards the press.
} 
When the Roman Catholic Church opposed the press, their opposition generally took the form of censorship and book burning rather than outright ban on printing in Latin characters. ${ }^{20}$ There were plenty of reasons why religious authorities wanted to control the spread of the press in Europe - most prominently, the success of the Reformation was dependent on the Reformers' ability to circulate vast amounts of pamphlets (Rubin 2011b). Indeed, the Church attempted to control the spread of books that challenged its interests through the repression of books during the Spanish Inquisition of the 1490s, the promulgation of the Index Librorum Prohibitorum ("List of Prohibited Books") in 1559, and executions of French publishers of Protestant literature (Febvre and Martin 1976). Moreover, the spread of Protestant propaganda worked well despite low literacy rates. Protestant tracts were generally read out loud in public places by traveling preachers or literate citizens, reducing the need for widespread literacy. Even more damning, the Reformers displayed their anti-papal propaganda in pictorial broadsheets, which were easily reproduced with the press. The difference from the Ottoman case was that the private opposition of religious leaders did not result in public bans on the technology that lasted a long time.

Using the framework of our model, we explain the differential reactions to the printing press by focusing on differences in sources of legitimacy between the Ottoman Empire and Western Europe. By the time of the advent of the press, the Church was a relatively weaker source of legitimacy for rulers in Western Europe as compared to the Ottoman Empire. Although there was significant heterogeneity throughout Europe, Church leaders lost much of their ability to offer legitimacy in the late-thirteenth century as a result of the growth of secular power into national kingdoms, new theories of the state based on Aristotelian foundations, and movements

\footnotetext{
${ }^{20}$ The Church was one of the earliest users of the press, using it to print ordinances, works of popular piety, bulls, indulgences, and propaganda for its anti-Turkish crusade (Febvre and Martin 1976; Eisenstein 1979).
} 
of criticisms within the Church (Tierney, 1988; Feldman, 1997). ${ }^{21}$ The loss of Church power in this period is perhaps best exemplified by the Avignon Papacy (1309-1377), where the papal chair was largely under control of the French monarch. Likewise, the growth of independent cities in Italy and the Holy Roman Empire, primarily on economic grounds, diminished the need for religious legitimacy. ${ }^{22}$ Another contributing factor was the significant difference in the cost of suppressing the new technology $(C(\theta))$. The cost was higher in Europe than in the Ottoman Empire because of greater jurisdictional competition among European states that provided alternatives to printers.

Moreover, the Church had lost its comparative advantage in the production of legitimacy through loyalty because it no longer had a monopoly on educational and intellectual (especially book-producing) institutions in Europe. The Church lost much of this power - which it had previously held via the book-producing efforts of the monasteries - by the thirteenth century when the newly-founded Universities began to undertake major book-publishing programs of both religious and secular tracts. ${ }^{23}$ The University Doctors translated the works of the early Church fathers as well as the philosophical treatises of the ancient Greeks, especially Aristotle. The central concentrations of supply and demand for books were thus near the Universities, not the monasteries or other Church holdings (Haskins, 1957: 38-53; Schachner, 1962; Christ, 1984: 237-238).

\footnotetext{
${ }^{21}$ This is in contrast to the period between the late $11^{\text {th }}$ century and the early $13^{\text {th }}$ century, where papal power vis-àvis secular rulers was at its height following the Investiture Controversy and the programme of Gregory VII (Feldman, 1997; Rubin, 2011a).

${ }^{22}$ For more on the economic effects of the independence of city-states, see Guiso, Sapienza, and Zingales (2008) and Jacob (2010). Guiso, Sapienza, and Zingales (2008) note that "the source of political power and legitimacy of authority [in the independent city-states] is not religious or dynastic, but comes from the people". This accords with Lopez (1971), Jones (1997), and Greif (2006), who argue that the Italian city-states were built by merchants for merchants. Though religion was extremely important in the communes, the interests of religious authorities were generally subordinate to those of the merchant elite.

${ }^{23}$ Christ, et. al. (1984: 297-310) notes a similar growth in the late twelfth century of a lay element in the type of books collected in libraries and the type of individuals amassing libraries. See also Febvre and Martin (1976: 22-25).
} 
As European rulers began to regain suzerainty over their lands in the late- $13^{\text {th }}$ century (diminishing their dependence on the Church for legitimacy), they also attempted - given the University's potential as a source of revenue - to wrestle control of the Universities away from the Church. Secular support for the Universities was widespread - during the Hundred Years' War both the French and English founded Universities to promote patriotic feelings, Florence established a University in order to repopulate after a plague, and numerous other cities solicited Universities in order to establish a new source of income (Schachner, 1962: 50). In particular, lay leaders supported the writing and copying of non-religious (especially political) tracts, which were not encouraged when the Church dominated the Universities (such works were "banned" or only written at high cost).

A feedback loop thus emerged between the growth of Universities, non-religious writing, and lay control. Lay magnates encouraged non-religious writing as the Universities grew, which in turn created greater demand and supply for such writing. These interactions burgeoned to the point where the Church accepted the validity of non-religious tracts, so long as they were not "heretical". The rise of the Universities, especially in their role as book producers, came about largely because they engendered a literary sphere that was outside and disassociated from the religious sphere. An important unintended consequence of the Universities, therefore, was that they established a separate sphere of book production, thus providing a setting in which, after the invention of the printing press, there was widespread demand for books over which the Church no longer held a monopoly on supply. As a result, the Church would have not been able to stop the spread of the press even if it had wanted to. While the Church often used presses for its own propaganda purposes, this should not be taken as evidence that the Church would have favored 
the press if it were in a stronger legitimizing position, but as a best response to broader economic realities under which the Church's ability to legitimize political authorities was weakened.

Caution must be taken, however, to not imply that the history of printing spread unimpeded throughout Europe after its invention in 1450. Much of the early history of printing is one of persecution by political and religious authorities, and printers often risked life and limb to produce controversial tracts (Febrve and Martin, 1958; Eisenstein, 1979; Love, 1993). Love (1993) documents that printing could be used just as easily against political authorities as it could in their support, and thus subversive tracts primarily remained confined to script for centuries after the spread of printing, allowing the scribal tradition to persist. Moreover, Johns (1998) argues that special interests, such as the Stationers in England (who were granted a monopoly on printing throughout the kingdom), were able to block some aspects of printing, sometimes violently.

These facts are very much in line with the theory presented in this paper. European rulers (kings, princes, etc.) had little incentive to suppress the welfare-enhancing aspects of printing (its economic returns, use for propaganda, etc.) because the socially optimal use of the technology $\left(\theta^{*}\right)$ did not reduce legitimacy and ruler's revenue as it did in the Ottoman Empire. On the other hand, because there were clearly negative (subversive) uses to printing, the optimal solution for European rulers (especially in England and France, where religious and political interests clashed throughout the $16^{\text {th }}$ and $17^{\text {th }}$ centuries) was to permit, but regulate, the press in a way that raised social surplus while controlling for its effect on private short-term interests and concerns. Moreover, our model - highlighting the role of legitimizing agents - also helps explain why the Ottomans did not use a similar "permit and regulate" tactic regarding printing in Ottoman Turkish. If they had done so, it would have undermined the religious authorities' ability to 
legitimize (which relied heavily on the oral transmission of all types of knowledge). Indeed, had Islamic religious authorities been undermined in a manner similar to the way that the Reformation undermined the Church, the effect on the Ottoman Sultans' legitimacy would have been devastating.

To summarize, the legitimizing relationship between the rulers and religious authorities differed between the Ottoman Empire and Western Europe at the time of the invention of the printing press. Combined with other differences between the two regions discussed earlier, especially literacy and urbanization, this meant that the net revenue available to the ruler due to the new technology was higher in Europe than in the Ottoman Empire. Mass printing raised the surplus available to the rulers by a greater magnitude in Europe than was possible in the Ottoman Empire, and it had a more negligible adverse effect on their legitimacy. As a result, European rulers were more eager than the Ottomans to accept the printing press.

\section{The Swift Adoption of Military Technology}

The discussion in the previous two sections cannot rule out the alternative argument, favored by the Orientalists, that Ottoman rulers were simply more conservative than their Western European counterparts. For such a hypothesis to be valid, it must have explanatory power relating to all types of technologies. Yet, the Ottoman eagerness towards military technology contrasts sharply with their attitude towards the printing press.

As one of the key players in the Eurasian power struggles of the late medieval and early modern periods, the Ottomans paid close attention to advancements in military technology. Contrary to some of the earlier writings that viewed the Ottomans as being cultural and technological conservatives and unable or unwilling to keep pace with western military 
technology, recent scholarship has shown that they were quite receptive to these advancements. ${ }^{24}$ As Agoston (2005: 192) has argued, the Ottomans "were quick to realize the advantages of firearms" and that "[t]he pragmatism and flexibility of the Ottoman ruling elite led to the relatively smooth integration of gunpowder weapons in the Ottoman army." The Ottomans not only kept pace with developments in gunpowder, firearms, and cannons but displayed ingenious organizational skills by pioneering the establishment of a permanent standing army (the Janissaries) specialized in the use of these weapons well before the European powers. They showed such remarkable success in assimilating gunpowder technology into their army and navy that by the mid-fifteenth century they achieved a clear logistical and firepower superiority over their European and Asian adversaries.

Our claim is that the Ottomans were eager to accept new military technologies during this period because they expected these advancements to raise the net revenue available to them. In terms of the model described in Section 2, advancements in military technology were accepted because they were expected to raise not only the size of the available surplus $\left(S\left(\theta^{*}\right)>S\right)$ but also the ability of military authorities to legitimize the ruler $\left(\beta(\theta)>\beta_{0}\right)$. Economic theory and historical evidence support these claims, as discussed in detail below.

Advancements in military technology raised the size of the surplus available to the Ottomans by expanding their revenue base through conquests and tributes or by helping them protect existing revenues from being confiscated by adversaries equipped with the new technology. Territorial expansion was a primary objective of the Ottoman sultans, and new

\footnotetext{
${ }^{24}$ For examples of previous claims made in the secondary generalist literature, see Cipolla (1966), Jones (1987: Chapter 9), Goldschmidt (2002: Chapter 9), Lewis (1982: Chapter 9). See also Agoston (2005: 7-13) for a critical review and refutation of these claims.
} 
military technologies were frequently used in this pursuit (Agoston, 2005). ${ }^{25}$ The demand for the new technology was clearly positive in this regard.

The effect of new technology on legitimizing relationships was also positive. As discussed earlier, legitimacy could come from two sources, loyalty and force. Whereas the religious authorities could confer legitimacy through loyalty, military authorities had a comparative advantage in the production of legitimacy by force, using manpower and weapons as inputs. A new military technology enhanced the ability of military authorities to confer legitimacy by raising its coercive capacity. For example, consider the technological advancements associated with the invention of the gunpowder. Prior to the invention of gunpowder weapons, the military generated credible force required to tax the citizenry only by sheer size, relying on significant manpower equipped with swords, bows, and arrows with limited power. Medieval states thus incurred high costs to control or maintain large armies aimed at preventing opposition to taxes or evasion. With the invention of firearms, the output of soldiers and weapons rose significantly, and the cost per unit of producing force fell. The result was a significant improvement in the ability of military authorities to confer legitimacy to the ruler and a significant fall in the amount of expenditures for the production of force required to obtain the surplus.

Ottoman sultans used the military extensively in tax collection. Under a prebendal mechanism of tax collection called the timar system, provincial cavalrymen (sipahis) collected taxes directly from the peasantry as remuneration for their military services to the state. Military personnel were also used in various capacities in the collection of other tax revenues. For example, according to finance department registers, a vast majority of those collecting the cizye,

\footnotetext{
${ }^{25}$ For the importance of gunpowder weapons in Eurasian warfare, see Black (1999) and Parker (1988). See also Murphey (1999) for Ottoman warfare between 1500 and 1700.
} 
a poll tax collected from religious minorities, were military personnel (Darling, 1996: 169). They were also increasingly involved in some capacity in tax-farming and in the collection of occasional taxes called the avartz and various other tax revenues for provincial offices or the central treasury (Darling, 1996: Chapter 5). ${ }^{26}$ By equipping soldiers with the latest weapons the military authorities thus increased their effectiveness not just on the battlefield but also in tax collection.

It took only a few decades from the time the Ottomans were acquainted with firearms in the 1380s for the Janissaries to start using them. The proportion of Janissaries using the firearms rose significantly during the fifteenth century, and by the mid-sixteenth century most of them were carrying the new weapons (Agoston, 2005: 23). The Ottomans also established artillery units and various other infantry troops armed with gunpowder weapons, using foreign experts as necessary for technical improvements. ${ }^{27}$

\section{Why the Printing Press was Eventually Accepted in the Ottoman Empire}

Finally, we return to the puzzle posed in Section 4, namely the question of why the Ottomans banned printing in Arabic characters. Our explanation, which relies on the effect of the press on the legitimizing ability of religious authorities, begs another question: Why did the Ottomans eventually relax the ban? For our theory to be consistent, something must have changed in the legitimizing relationship between the Sultan and his agents in the period between the initial ban and the eventual acceptance of the press.

\footnotetext{
${ }^{26}$ For example, according to tax-farming registers of 1603-4, almost two-thirds of tax-farmers were of military origin (Darling, 1996: 179).

${ }^{27}$ Although there was some delay in the introduction of firearms to provincial cavalrymen, this was primarily because of the inadequacy of early firearms to cavalry corps and the desire of the central government to control the spread of weapons in the countryside.
} 
The Ottomans relaxed the ban on printing in Arabic characters in 1726, giving exclusive rights to İbrahim Müteferrika and his partner to print in Ottoman Turkish. But they continued to heavily regulate the operation by granting permission only to selected individuals, prohibiting publication in religious subjects, and appointing a committee of scholars to review and proofread contents for accuracy. ${ }^{28}$ Following an intermittent presence in the eighteenth century, during which only 33 books were published, the industry grew quickly in the nineteenth century. The ban on Islamic subjects was lifted in 1802, and the lithographic press was adopted soon after its invention in Germany. In the decade following the creation of Takvimhane-i Âmire in 1831 to print the first official newspaper, six new presses were founded, publishing a total of 278 books. Sixty $(22 \%)$ of these books were on religious subjects. Thirteen new presses were launched in the next decade, altogether publishing a total of 394 books ( $31 \%$ on religious subjects). ${ }^{29}$ The industry was well-established by mid-nineteenth century, with the state actively involved through school books, official newspapers, and various administrative publications.

The adoption of the printing press was closely related to two parallel developments. The first was a significant change in the internal organization of the religious establishment in the seventeenth century, particularly in appointments and incentives. Appointment was increasingly centralized during this period, recruits coming primarily from schools in Istanbul rather than provinces, promotions being based on connections and wealth rather than merit or seniority, and prominent families dominating the highest ranks over several generations. Privilege was institutionalized in an aristocratic organization, as 12 of the 42 chief jurisconsults (şeyhülislam) who occupied the top of the hierarchy during the seventeenth century came from only five

\footnotetext{
${ }^{28}$ Within a few years after Müteferrika's enterprise printed the first book in 1729, Sait Efendi quit the partnership. Although Müteferrika continued the business, he was able to publish only 17 books until he fell ill in 1743. From his death in 1745 to the end of the century, the industry underwent a long period of intermissions and failed restarts, producing only 16 additional books (Baysal 1968).

${ }^{29}$ Calculated from the information presented in Baysal (1968: 40-42).
} 
families. The proportion rose in the eighteenth century, with half of the 58 chief jurisconsults appointed between 1708 and 1839 coming from 11 families (Zilfi, 1988: 47-48). The structure of incentives also changed because of the misalignment between the leadership and rank and file and growing resentment among membership at the lower local levels. Corruption, though always present in previous centuries, rose to unprecedented levels during the seventeenth century, affecting the delivery of services at the local level and diminishing the reputation of the religious establishment as a whole (Zilfi, 1988: Chapter 1).

As religious authorities suffered a loss in reputation and capacity to offer services at the local level, they gradually lost their comparative advantage in providing legitimacy through loyalty. By actively participating in palace politics in the seventeenth century, they had put their influence at risk, and the establishment was no longer a monolithic entity in supporting the ruler (Zilfi, 1988: 110-21). Estranged from the leaders, members at the lower local levels had greater incentive to turn against authority than to promote the sultan's right to rule and collect taxes (Heyd, 1961: 72). As Repp (1999: 805) has observed, "by the 18th century a virtually closed aristocracy of the 'ulamá' had come into being which had little to do with the traditional roles of the 'ulama' as transmitters of Islamic learning, as exemplars of piety, or as mediators between the rulers and the ruled." Although the Empire retained its fundamentally Islamic character, and the higher ranks of the religious hierarchy continued to play an important role in imperial politics, the ability of religious authorities to provide legitimacy through loyalty was significantly diminished by the beginning of the eighteenth century.

A parallel development was the rising importance of the notables ( $\left.a^{\prime} y \bar{a} n\right)$ as secular authorities in Ottoman provincial society and administration during the seventeenth century (İnalcık, 1977; Özkaya, 1994; Hourani, 1981). The Ottoman government had long relied on 
distinguished inhabitants of provincial towns as informal intermediaries between the central administration and general public. These notables had been assisting the central government in gathering information, enforcing regulations, and providing protection at the local level. As İnalc1k (1977: 44) notes, "in the course of the seventeenth century [the control of the notables] over public affairs steadily increased [such that] beginning in the decade of 1680 , the sources indicate the presence in each kaza of a single ayan who was its representative and who was elected to his position by his local peers." Acquiring official status, the notables gained greater political power as recognized representatives of local interests to the central government.

The rising importance of the notables changed the sources of legitimacy available to Ottoman rulers. As discussed earlier, the notables could produce legitimacy from a different source than religious loyalty, namely local connection and secular allegiance. Elected by the local subjects and approved by the ruler, they derived power from representing the people vis-àvis the government. As Göçek (1996: 62) documents from the Ottoman archives, they built power through political ties with the subjects, "ties that the sultan could not obliterate." As providers of justice, protection, and other public goods, they acquired an enormous capacity to legitimize the ruler, emanating not from the ruler but from his subjects. In this capacity, they participated in "the maintenance of public buildings ... and in the performance of related public services," facilitated the delivery of the avartz tax by "[coming] forward with the funds on behalf of the local citizens and later collect[ing] from them", and even "run[ning] down bandits in the region." (İnalc1k, 1977: 44-45). While the religious authorities experienced a decline in their ability to confer legitimacy, that of the notables rose during this period.

As returns from religious and secular sources of loyalty changed in the seventeenth and eighteenth centuries, the Ottomans gradually shifted investment toward the the notables to confer 
legitimacy. The primary instrument of their relationship with the notables was the Sultan's prerogative to appoint individuals to collect taxes on behalf of the government. From the seventeenth century onward, the government increasingly appointed local notables as tax farmers, facilitating their rise to prominence in the provinces. By the eighteenth century they had assumed "both de facto and de jure authority formerly exercised exclusively by the governors" (İnalcık, 1977: 32). If some members of the religious establishment also received appointments as tax farmers, they did so primarily by joining the ranks of the notables. To prevent opportunistic behavior, the Ottomans introduced the institution of lifetime farms (mālikāne), forming a better alignment between the interests of the notables and those of the ruler in taxation. Since the notables, as lifetime tax farmers, had an interest in maximizing taxable revenues and minimizing resistance to taxation, any resource allocated to the notables was ultimately an investment toward promoting the ruler's legitimacy (as defined in our model).

These developments altered the parameters of the ruler's decision on the printing press drastically, tilting the balance in favor of relaxing some of the restrictions on the new technology. The framework presented in this paper suggests that when the returns from "purchasing" one source of legitimacy (religious) diminish relative to another (secular), the ruler will begin to accept - or not disallow - surplus-enhancing technologies that harm the former's ability to legitimize. As the notables presented an alternative source of legitimacy, mass printing was less of a threat to the legitimacy of the ruler in the eighteenth century. The notables did not risk losing their ability to confer legitimacy with the introduction of the printing press ${ }^{30}$ their ability to legitimize depended on their capacity to provide representation and local public goods, not on a monopoly over the transmission of knowledge. The alternative form of legitimacy that

\footnotetext{
${ }^{30}$ One could even argue that mass printing improved the ability of the notables to legitimize the ruler if higher literacy and greater knowledge enhanced their reputation among the citizenry and their success as representatives.
} 
the notables offered reduced the press' overall effect on the ruler. Shifting from religious authorities to local notables for legitimacy meant the rulers no longer needed to suppress this welfare-enhancing invention indefinitely. This argument does not entail that the Ottoman sultans simultaneously eschewed religious legitimacy; instead, it suggests that the emergence of a substitutable source of legitimacy (the notables) provided incentives that made weakening the restrictions on the printing press more attractive on the margin.

The potential effect of the printing press on the size of the social surplus also increased between the fifteenth and eighteenth centuries. The demand for books and other publications likely grew during this period because of higher rates of literacy and urbanization, though we have no direct data to confirm this expectation reliably. The printing technology also improved, such as in the casting of fonts and the production of paper, which lowered the cost of production significantly. Yet, supply and demand explanations alone cannot be at the heart of the severe restrictions on printing. Surely there was sufficient supply and demand for books from the beginning so that an industry could have succeeded in the absence of severe restrictions, and a purely economic reason cannot suffice to explain the behavior of the Ottoman rulers. In fact, the publication industry performed well enough in the nineteenth century to indicate that the productive capacity of mass printing in the Ottoman Empire had vastly improved during this period. $^{31}$

These developments indicate that printing in Arabic characters presented less of a threat to the ruler's legitimacy in the eighteenth century, and its expected benefits to the ruler's revenue had grown even larger. The Ottomans eventually relaxed the ban on new technology because its

\footnotetext{
31 The Ottoman publication industry did not take off immediately after the adoption of the printing press in the eighteenth century. But this was more a result of the ruler's regulation of the industry as a government-granted monopoly and restrictions on permissible publications, particularly the ban on religious subjects, than an indicator of its capacity to generate profits. As discussed above, the industry did ultimately take off in the nineteenth century, soon after the government relaxed the regulations and restrictions.
} 
cost and benefits had changed significantly between the fifteenth and eighteenth centuries, as can be seen as an upward shift of the $\beta(\theta) S(\theta)-C(\theta)$ curve in Figure 1. They allowed printing in Arabic characters in 1726 because by then they were on balance better off adopting mass printing than suppressing it.

\section{Conclusion}

To explain the differential reaction of the Ottomans to military and mass printing technologies and why their reaction to the printing press changed over time and differed from that of contemporary European states, we have focused on the economic incentives of political actors and the political economy of technological advancements. A new technology changed not just the productivity of workers but also the legitimizing relationship between the rulers and their agents. The rulers needed support from military, religious, and secular agents to reduce the cost of collecting taxes, which depended on the ability of agents to legitimize the ruler under the prevailing technological regime. Since a new technology could alter legitimizing relationships, the ruler's choice of whether to allow or suppress the technology depended on how it affected his net revenue.

The Ottoman reaction to the printing press was different from their reaction to military technologies and the reaction of the Europeans to printing press. Although mass printing could have raised economic productivity and the size of the surplus available to the ruler for taxation, the Ottomans chose to forego the opportunity and regulate the technology heavily for almost three centuries by banning printing in Arabic characters. They were not initially enthusiastic about the new technology because they expected it to lower their net revenue by undermining the ability of religious authorities to generate loyalty. The European rulers, on the other hand, were 
generally open to the adoption of mass printing because they relied on religious legitimacy to a lesser extent at the time of the invention of the press.

The Ottomans started to relax the restrictions on the printing press in the eighteenth century. New sources of legitimacy gained importance in the intervening centuries, and hence it mattered less that the printing press threatened the ability of religious authorities to produce loyalty. Its expected benefits to the ruler's revenue had also increased, so the Ottomans deregulated the technology when its expected benefits exceeded the cost. 


\section{References}

Acemoglu, D. \& Robinson, J.A. 2006. "Economic Backwardness in Political Perspective", American Political Science Review, vol. 100, no. 1, pp. 115-131.

Adıvar, A.A. 1943. Osmanlı Türklerinde ilim, 2. tabı edn, İstanbul: Maarif matbaası.

Ágoston, G. 2005. Guns for the sultan: military power and the weapons industry in the Ottoman Empire, Cambridge: Cambridge University Press.

Atiyeh, G.N. 1995. The book in the Islamic world: the written word and communication in the Middle East, Albany: State University of New York Press.

Babinger, F., İbrahim Müteferrika, Burçoğlu, N.K. \& Kiel, M. 2004. Müteferrika ve Osmanlı matbaası, İstanbul: Türkiye Ekonomik ve Toplumsal Tarih Vakfi.

Barkan, Ö.L. 1953. "Tarihi demografi araştırmaları ve Osmanlı tarihi," Türkiyat Mecmuası, vol. 10, pp. 1-26.

Baten, J. \& van Zanden, J.L. 2008. "Book Production and the Onset of Modern Economic Growth", Journal of Economic Growth, vol. 13, no. 3, pp. 217-235.

Baysal, J. 1968. Mü̈eferrikadán Birinci Mesfutiyete kadar Osmanlı Tü̈klerinin bastıkları kitaplar, 1. bask1 edn, Istanbul.

Beetham, D. 1991. The legitimation of power, Atlantic Heights, NJ: Humanities Press International.

Berkes, N. 1962. "İlk Türk Matbaası Kurucusunun Dinî ve Fikrî Kimliği", Belleten, vol. XXVI/104, pp. 715-37.

Black, J. 1999. European warfare, 1453-1815, New York: St. Martin's Press.

Buringh, E., \& van Zanden, J. L. 2009. Charting the 'rise of the west': Manuscripts and printed books in Europe, a long-term perspective from the sixth through eighteenth centuries. Journal of Economic History, vol. 69, no. 2, pp. 409-445.

Chaudhary, L., \& Rubin, J. 2011. "Reading, Writing, and Religion: Institutions and Human Capital Formation.” Journal of Comparative Economics, vol. 39, no. 1, pp. 17-33.

Chilosi, David and Oliver Volckart. 2010. "Books or Bullion? Printing, Mining and Financial Integration in Central Europe from the 1460s.” LSE Working Paper 144/10.

Christ, K., Kern, A. \& Otto, T.M. 1984. The handbook of medieval library history, Metuchen, N.J.: Scarecrow Press.

Cipolla, C.M. 1966. Guns, sails and empires: technological innovation and the early phases of European expansion, 1400-1700, New York: Pantheon Books.

Coşgel, M. M. 2005. "Efficiency and continuity in public finance: The Ottoman system of taxation." International Journal of Middle East Studies, vol. 37, no. 4, pp. 567-586.

Coşgel, M. M., \& Miceli, T. J. 2005. Risk, transaction costs, and tax assignment: Government finance in the Ottoman Empire." Journal of Economic History, vol. 65, no. 3, pp. 806-821.

Coşgel, M.M, and Miceli, T. 2009. "State and Religion," Journal of Comparative Economics, vol. 37, pp. 402-16.

Coşgel, M.M., Miceli, T. \& Ahmed, R. 2009. "Law, state power, and taxation in Islamic history", Journal of Economic Behavior and Organization, vol. 71, no. 3, pp. 704-717.

Darling, L.T. 1996, Revenue-raising and legitimacy: tax collection and finance administration in the Ottoman Empire, 1560-1660, Leiden: E.J. Brill.

Dittmar, J. 2011. "Information Technology and Economic Change: The Impact of the Printing Press", Quarterly Journal of Economics, vol. 126, no. 3, pp. 1133-1172. 
Eisenstein, E.L. 1979. The printing press as an agent of change: communications and cultural transformations in early modern Europe, Cambridge: Cambridge University Press.

Febvre, L.P.V. \& Martin, H. 1976. The coming of the book: the impact of printing, 1450-1800, London: Verso.

Feldman, S.M. 1997. Please don't wish me a Merry Christmas: A critical history of the separation of church and state, New York: New York University Press.

Finkel, C. 2005. Osman's dream: The story of the Ottoman Empire, 1300-1923, London: Perseus Books.

Gerçek, S.N. 1939. Türk matbaacıllı̆g. İstanbul: Devlet basımevi.

Ghobrial, J. 2005. "Diglossia and the 'Methodology' of Arabic print," Paper presented at the 2nd International Symposium "History of Printing and Publishing in the Languages and Countries of the Middle East" 2 - 4 November 2005, Paris: Bibliothèque nationale de France.

Gilley, B. 2009. The right to rule: How states win and lose legitimacy. New York: Columbia University Press.

Göçek, F.M. 1996. Rise of the bourgeoisie, demise of empire: Ottoman westernization and social change, Oxford: Oxford University Press.

Göçek, F.M. 1987. East encounters West: France and the Ottoman Empire in the eighteenth century, Oxford: Oxford University Press.

Goldschmidt, A. 2002. A concise history of the Middle East 7th edn, Boulder: Westview Press.

Greif, A. 2002. "The Islamic Equilibrium: Legitimacy and Political, Social, and Economic Outcomes", Working Paper.

Greif, A. 2006. Institutions and the Path to the Modern Economy, Cambridge: Cambridge University Press.

Greif, A. 2010. "A Theory of Moral Authority: Moral Choices under Moral Network Externalities." Working paper.

Greif, A. \& Laitin, D. 2004. "A Theory of Endogenous Institutional Change.” American Political Science Review vol. 98, no. 4, pp. 633-652.

Greif, A. \& Tadelis, S. 2010. "A Theory of Moral Persistence: Crypto-morality and Political Legitimacy." Journal of Comparative Economics, vol. 38, no. 3, pp. 229-244.

Guiso, L., Spienza, P. \& Zingales, L. 2008. “Long Term Persistence”, NBER Working Paper no. 14278.

Hardin, R. 2007. "Compliance, Consent, and Legitimacy" in The Oxford handbook of comparative politics, eds. C. Boix \& S.C. Stokes, Oxford: Oxford University Press, pp. 236-255.

Haskins, C.H. 1957. The rise of universities, Ithaca: Great Seal Books.

Heyd, U. 1961. "The Ottoman 'Ulemā and Westernization in the Time of Selīm III and Mahmūd II", Scripta Hierosolymitana, vol. 9, pp. 334-57.

Hurrell, A. 2005. "Legitimacy and the Use of Force: Can the Circle Be Squared?" Review of International Studies, vol. 31, pp. 15-32.

Hourani, A. 1981. "Ottoman reform and the politics of notables," in Emergence of the Modern Middle East, A. Hourani, Berkeley: University of California Press, pp. 36-66.

Huff, T.E. 1993. The Rise of Early Modern Science, Cambridge: Cambridge University Press. Iannaccone, L. R. \& Berman, E. 2006. "Religious extremism: the good, the bad, and the deadly," Public Choice, vol. 128, pp. 109-129. 
Ibn Khaldûn. 1967. The muqaddimah: an introduction to history. London: Routledge \& Kegan Paul.

Imber, C. 1997. Ebu's-su-ud: The islamic legal tradition. Stanford: Stanford University Press. İnalc1k, H. 1977. "Centralization and Decentralization in Ottoman Administration" in Studies in Eighteenth Century Islamic History, eds. T. Naff \& R. Owen, Carbondale: Southern Illinois University Press, pp. 52.

Jacob, M. 2010. "Long-Term Persistence: The Free and Imperial City Experience in Germany", Working Paper.

Johns, A. 1998. The nature of the book: print and knowledge in the making, Chicago: University of Chicago Press.

Jones, E.L. 1987. The European miracle: environments, economies, and geopolitics in the history of Europe and Asia, 2nd edn, Cambridge: Cambridge University Press.

Jones, P. 1997. The Italian City-State: From Commune to Signoria, Oxford: Clarendon Press.

Kuran, T. 2004. Islam and Mammon: The Economic Predicaments of Islamism. Princeton: Princeton University Press.

Kuran, T. 2010. The long divergence. Princeton: Princeton University Press.

Krusell, P. \& Rios-Rull, J. 1996. "Vested Interests in a Positive Theory of Stagnation and Growth", Review of Economic Studies, vol. 63, no. 2, pp. 301-329.

Kut, G.A. 1991. "Matba'a. 2. In Turkey" in The Encyclopaedia of Islam, New , edn, Leiden: Brill, pp. 799-803.

Levi, M. 1988. Of rule and revenue. Berkeley: University of California Press.

Lewis, B. 1982. The Muslim discovery of Europe, 1st edn, New York: W.W. Norton.

Lopez, R.S. 1971. The Commercial Revolution of the Middle Ages, 950-1350, Cambridge: Cambridge University Press.

Love, H. 1993. Scribal publication in Seventeenth-Century England, Oxford: Oxford University Press.

Mann, M. 1986. The Sources of Social Power: A history of power from the beginning to A.D. 1760, Cambridge: Cambridge University Press.

Mokyr, J. 1990. The lever of riches, Oxford: Oxford University Press.

Mokyr, J. 2002. The gifts of Athena: Historical origins of the knowledge economy, Princeton: Princeton University Press.

Murphey, R. 1999. Ottoman warfare, 1500-1700, New Brunswick: Rutgers University Press.

Mystakidis, B.A., 1911. "Hükümet-i Osmaniye tarafından ilk tesis olunan matbaa ve bunun sirayeti,"Türk Tarih Encümeni Dergisi I: pp. 322-28, 451-58.

Nasr, S.H. 1995. "Oral Transmission and the Book in Islamic Education" in The book in the Islamic world: the written word and communication in the Middle East, ed. G.N. Atiyeh, Albany: State University of New York Press, pp. 57-70.

North, D.C. 1990. Institutions, Institutional Change, and Economic Performance. Cambridge, Cambridge University Press.

Olson, M. 1982. The rise and decline of nations: economic growth, stagflation, and social rigidities, New Haven: Yale University Press.

Özkaya, Y. 1994. Osmanli Imparatorlugu'nda âyânlik, Türk Tarih Kurumu Basimevi, Ankara.

Özmucur, S. \& Pamuk, S. 2002. "Real Wages and Standards of Living in the Ottoman Empire, 1489-1914", Journal of Economic History, vol. 62, no. 2, pp. 293-321.

Parker, G. 1988. The military revolution: military innovation and the rise of the west, 1500-1800, Cambridge: Cambridge University Press. 
Pedersen, J. 1984. The Arabic Book, Princeton: Princeton University Press.

Platteau, J-P. 2008. "Religion, Politics, and Development: Lessons from the Lands of Islam", Journal of Economic Behavior \& Organization, vol. 68, no. 2, pp. 329-351.

Potrafke, N. 2011. "Islam and democracy" Public Choice, vol. 146, forthcoming.

Quataert, D. 2000. The Ottoman Empire, 1700-1922, Cambridge: Cambridge University Press.

Robinson, F. 1993. "Technology and Religious Change: Islam and the Impact of Print", Modern Asian Studies, vol. 27, no. 1, pp. 229-251.

Robinson, F. 1996. "Knowledge, Its Transmission and the Making of Muslim Societies," In F. Robinson (Ed.), The Cambridge illustrated history of the Islamic world. Cambridge: Cambridge University Press, pp. 208-49.

Repp, R. 1999. 'Ulamā in Ottoman Turkey. The Encyclopaedia of Islam (New ed.). Leiden: Brill, pp. 805.

Roper, G. 2007. The printing press and change in the Arab world. In S. A. Baron, E. N. Lindquist \& E. F. Shevlin (Eds.), Agent of change: Print culture studies after Elizabeth L. Eisenstein. Amherst: University of Massachusetts Press, pp. 250-267.

Roper, G. 2010. The history of the book in the Muslim world. In M. F. Suarez, \& H. R. Woudhuysen (Eds.), The Oxford companion to the book. Oxford: Oxford University Press, pp. 321-339.

Rubin, J. 2011a. "Institutions, the Rise of Commerce, and the Persistence of Laws: Interest Restrictions in Islam \& Christianity”, Economic Journal, vol. 121, no. 557, pp. 13101339.

Rubin, J. 2011b. "Printing and Protestants: Reforming the Economics of the Reformation", Working Paper.

Sabev, O. 2006. İbrahim Müteferrika ya da İlk Osmanli Matbaa Serüveni (1726-1746): Yeniden Degerlendirme Istanbul: Yeditepe,.

Said, E.W. 1978. Orientalism, 1st edn, New York: Pantheon Books.

Savage-Smith, E. 2003. "Islam" in The Cambridge history of science. Vol. 4. Eighteenth-century science, ed. R. Porter, Cambridge: Cambridge University Press.

Schachner, N. 1962. The mediaeval universities, New York: A. S. Barnes.

Szyliowicz, J.S. 1986. "Functional Perspectives on Technology: the Case of the Printing Press in the Ottoman Empire", Archivum Ottomanicum, vol. 11, pp. 249-259.

Tekiner, E. 1916. "Memâlik-i Osmaniye'de T1bâatim Kıdemi," T ürk Tarih Encümeni Dergisi VII: 242-49.

Tierney, B. 1988. The Crisis of Church and State 1050-1300, Toronto: University of Toronto Press.

Topdemir, H.G. 2002. İbrahim Müteferrika ve Türk Matbaacılı̆̆l, Ankara: Kültür Bakanlığı.

Wintrobe, R. 1998. The political economy of dictatorship, Cambridge: Cambridge University Press.

Zilfi, M.C. 1988. The politics of piety: the Ottoman ulema in the Postclassical Age (1600-1800), Minneapolis: Bibliotheca Islamica. 
Figure 1. Possible strategies of the ruler with respect to a new technology.

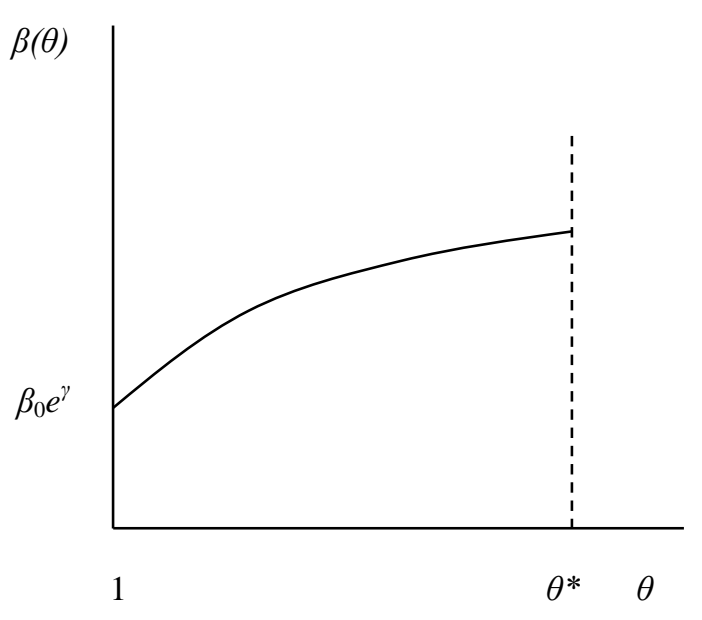

Effective tax rate

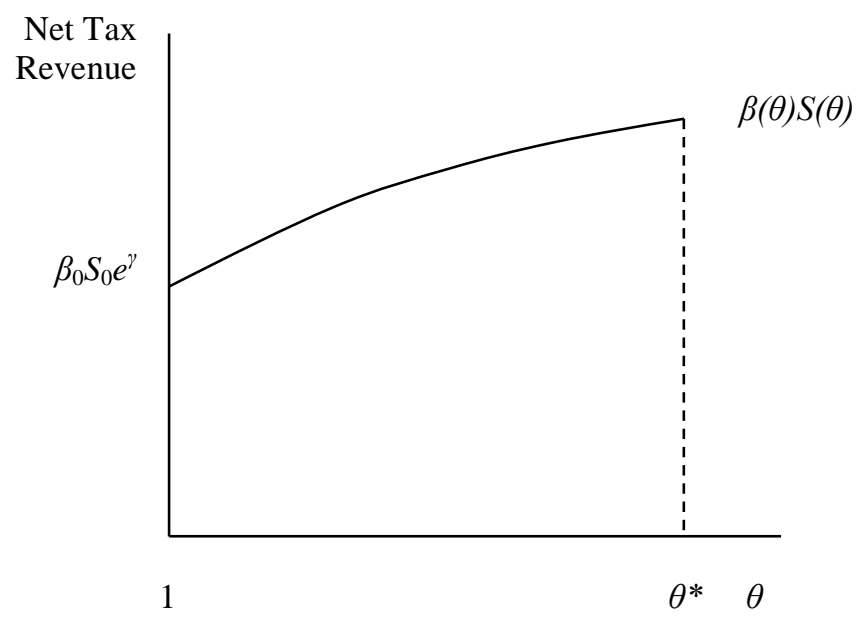

Net tax revenue

(a) Case 1: Allow the technology without restrictions $\left(\theta=\theta^{*}\right) ; \gamma>-1 / \theta^{*}$.

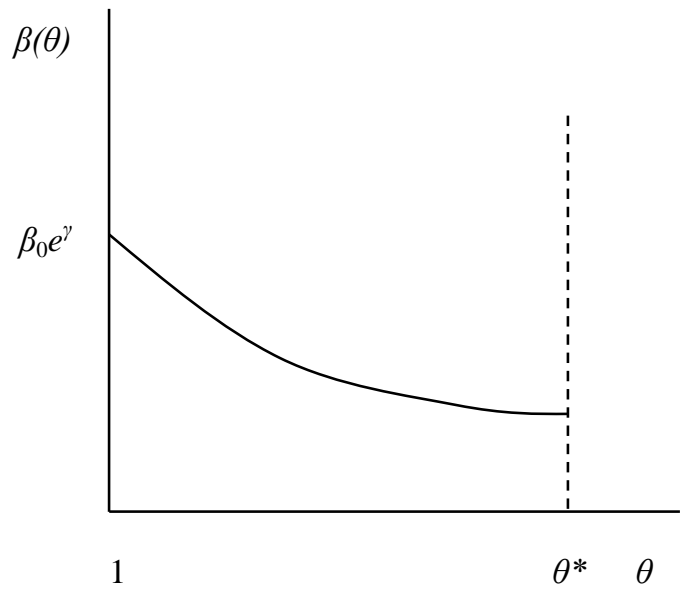

Effective tax rate

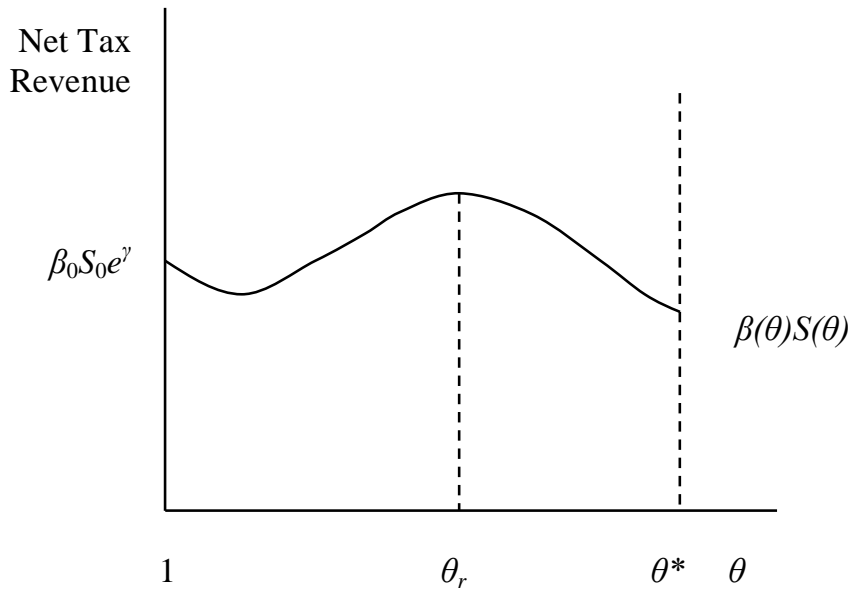

Net tax revenue

(b) Case 2: Allow the technology with restrictions $\left(\theta=\theta_{r}\right) ;-1<\gamma<-1 / \theta^{*}$. 


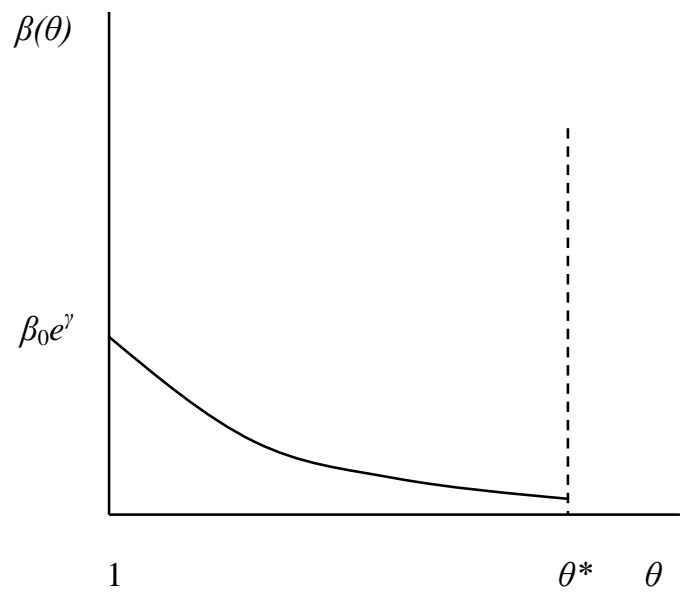

Effective tax rate

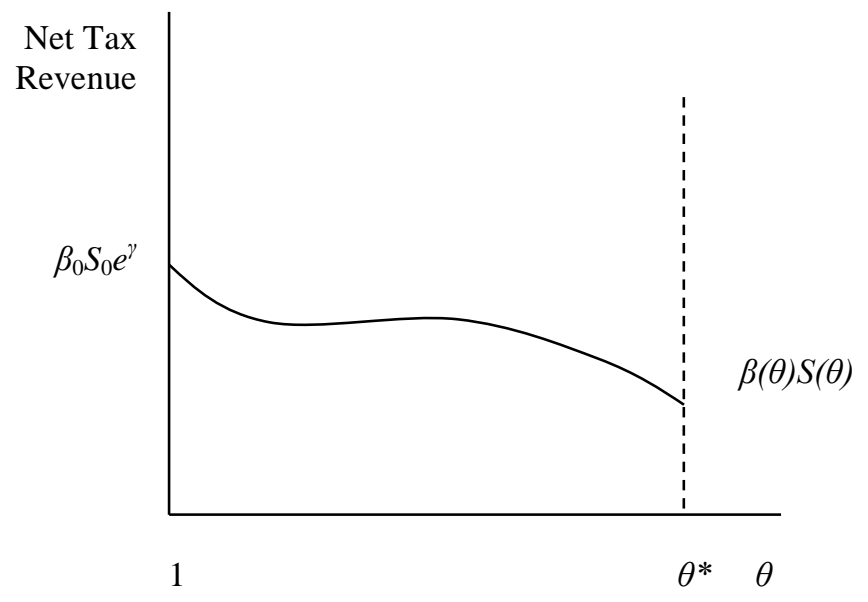

Net tax revenue

(c) Case 3: Suppress the technology $(\theta=1) ; \gamma<-1$. 